\title{
Method for estimating in situ chemolithotrophic ammonium oxidation using carbon monoxide oxidation*
}

\author{
Ronald D. Jones, Richard Y. Morita and Robert P. Griffiths \\ Department of Microbiology and College of Oceanography, Oregon State University, Corvallis, Oregon 97331-3804, USA
}

\begin{abstract}
A sensitive new method for estimating chemolithotrophic ammonium oxidation (nitrification) has been developed. Carbon monoxide oxidation, using ${ }^{14} \mathrm{CO}$, is measured with and without the addition of $100 \mathrm{mg} \mathrm{l}^{-1}$ of $\mathrm{N}$-Serve, a specific nitrification inhibitor. The $\mathrm{N}$-Serve sensitive CO oxidation can be related to the rate of ammonium oxidation by chemolithotrophic ammonium oxidizers. Methane oxidation, using ${ }^{14} \mathrm{CH}_{4}$, is also measured to determine the potential for ammonium and $\mathrm{CO}$ oxidation by methane oxidizer populations. This method was used to examine pure cultures of ammonium and methane oxidizers, as well as organisms in soil, 2 freshwater lakes, and estuarine waters. Ammonium oxidizers were found to be responsible for 28 to $97 \%$ of the CO oxidation in the environmental samples examined. Ammonium and methane oxidizers were found to have widely different $\mathrm{CH}_{4}$ oxidation to $\mathrm{CO}$ oxidation ratios, allowing distinction between environmental types where ammonium oxidizers achieve dominance.
\end{abstract}

\section{INTRODUCTION}

Several methods are currently in use or have been proposed for the estimation of nitrification in the environment. These include mass balance approaches using unlabeled substrates (Schwert and White, 1974; Billen, 1975; Webb and Wiebe, 1975); blockage of nitrite oxidation by chlorate and measurement of nitrite accumulation (Belser and Mays, 1980); estimation of nitrification potentials by adding high concentrations of $\mathrm{NH}_{4}^{+}$and determining nitrite and nitrate production; dark incorportion of ${ }^{14} \mathrm{C}$-bicarbonate in the presence and absence of N-Serve (Billen, 1976); population estimates, using either most probable number (MPN) or fluorescent antibody (FA) and estimating activities from these values (Belser, 1979); and ${ }^{15} \mathrm{~N}$ tracer techniques (Dugdale and Goering, 1967; Wada et al., 1977; Ohmori et al., 1981). All of the techniques mentioned thus far suffer from major drawbacks which have kept them from being used extensively. The major limitations include lack of sensitivity, disturbance of the populations by the addition of excessive substrate and the effects of lengthy incubation times.

- Published as Technical Paper No. 7127, Oregon Agricultural Experiment Station
The mass balance approach is only applicable in situations where a differential exists between $\mathrm{NH}_{4}^{+}$and $\mathrm{NO}_{2}^{-}$oxidation rates or where a specific water mass can be traced with time, as in a river. In addition it is very insensitive and is subject to a great deal of sampling error. These factors make it inadequate for nitrification rate determinations in most systems. The chlorate block method has been shown to have severe limitations in its applicability (Hynes and Knowles, 1983) in that the nitrite oxidizers are able to reduce chlorate to chlorite, which is an effective inhibitor of ammonium oxidation. The ${ }^{14} \mathrm{C}$-bicarbonate method proposed by Billen (1976) has also been demonstrated to have several limitations (Hall, 1982). Although the method is fairly sensitive and only requires 3 to $6 \mathrm{~h}$ incubation times it fails to consider the lack of coupling between ammonium oxidation and $\mathrm{CO}_{2}$ incorporation over a range of environmental conditions. It also fails to take into consideration the methane oxidizers which are also inhibited by $\mathrm{N}$-Serve and incorporate $\mathrm{CO}_{2}$ autotrophically (Topp and Knowles, 1982). The use of nitrification potentials provides limited information about natural systems and is unusable to examine most aquatic systems. Population estimates while providing some information about the composition of the system, provide little information that can be coupled 
to nitrification rates (Ward et al., 1982). In addition they severely underestimate the population size (Belser and Mays, 1982) which in turn gives excessively low nitrification rates (Wilson, 1965; Carlucci and Strickland, 1968). The ${ }^{15} \mathrm{~N}$ tracer technique also results in experimental problems. The addition of substrate results in an unavoidable perturbation of the system at a point where the kinetics are most sensitive (limiting substrate levels). Large sample size (ca. 4 l) and lengthy incubation times are necessary to obtain measurable results. In addition the sensitivity of the method is not great, lower quantities of nitrite formation can be detected using colorometric methods (Bendschneider and Robinson, 1952). Despite these disadvantages the use of ${ }^{15} \mathrm{~N}$ is at the present time the only method that allows the direct determination of in situ nitrification rates, that does not rely on other factors $\left(\mathrm{CO}_{2}\right.$ uptake, chlorate inhibition).

It has been demonstrated recently that ammonium oxidizers have the ability to oxidize both methane (Hyman and Wood, 1983; Jones and Morita, 1983a) and carbon monoxide (Jones and Morita, 1983b). In addition it has also been reported that N-Serve [2-chloro-6(trichloromethyl)pyridine] (NS), a known inhibitor of chemolithotrophic ammonium oxidation (Goring, 1962), will inhibit these oxidations (Jones and Morita, ms submitted).

This paper will address the use of $\mathrm{CO}$ and $\mathrm{CH}_{4}$ oxidation by the chemolithotrophic ammonium oxidizers as an index of their activity. It will also examine the applicability of this method to soil, lake, and an estuarine environments.

\section{MATERIALS AND METHODS}

Cultures and inoculum. Cultures of the methane oxidizers, Methylocystis parvus (OBBP), Methylosinus trichosporium (OB3B) and Methylomonas albus (BG8) (provided by C. Murrell) and a marine isolate, designated SA, from the surface waters of Sannich Inlet, Vancouver Island, British Columbia, isolated in our laboratory, were used in this study. Methane oxidizers were grown in $60 \mathrm{ml}$ serum bottles containing $25 \mathrm{ml}$ of the ammonium free medium used for the ammonium oxidizers (Jones and Morita, 1983a) supplemented with $1.0 \mathrm{~g}^{-1}$ of $\mathrm{KNO}_{3}$ as a nitrogen source. The $\mathrm{pH}$ was adjusted to 6.8 for the freshwater isolates and 7.8 for the marine isolate. The serum bottles were inoculated and then capped with butyl rubber serum stoppers and aluminum crimp seals (Bellco) and pressurized to 10 psi with methane gas (Airco, Grade 4 ultra pure). Bottles were incubated at $25^{\circ} \mathrm{C}$ on a rotary shaker. Samples were taken during log phase of growth (36 to $72 \mathrm{~h}$ depending upon the organism) and again during cell senescence ( $3 \mathrm{wk}$ ). These samples were subjected to cell counts, using acridine orange fluorescent microscopy (Hobbie et al., 1977). Portions $(1.0 \mathrm{ml}$ ) of these cultures were used to examine the rates of $\mathrm{CO}$ and $\mathrm{CH}_{4}$ oxidation.

The preparation of Nitrosomonas europaea, Nitrosomonas sp. 4W30 and Nitrosococcus oceanus cultures used in this study was identical to that described previously (Jones and Morita, 1983b).

Field samples and sampling. Soil samples were collected from an uncultivated meadow and a garden site within the meadow near Silverton, Oregon. The soils have been under the present state of cultivation for at least the last $7 \mathrm{yr}$. The garden soil has received regular additions of fertilizer and lime during this time. Soil $\mathrm{pH}$ values were 5.08 for the uncultivated soil and 5.10 for the garden soil. The top $5 \mathrm{~cm}$ of soil was collected, air dried and returned to the laboratory. Soil was then sieved $(1.0 \mathrm{~mm})$, soil mosilure was determined and adjusted to $23 \%$ using distilled water. Portions of these soils were used for the analyses.

The lakes examined were 2 lakes in the blast zone of Mt. St. Helens, Washington. They were North Coldwater Lake and Spirit Lake. A more complete description of these lakes can be found in Baross et al. (1982). Water samples were collected with a 51 Niskin bottle at the surface, top, middle, and bottom of the thermocline and at $40 \mathrm{~m}$. Samples for $\mathrm{CO}, \mathrm{CO}-\mathrm{NS}$, and $\mathrm{CH}_{4}$ oxidation were worked up in the field within $1 \mathrm{~h}$ of collection. North Coldwater Lake was sampled on 18 July 1983 and Spirit Lake was sampled on 19 July 1983.

Yaquina Bay, a small estuary on the Pacific Ocean near Newport, Oregon, was also examined during this study. The estuary is ocean dominated during the summer and fall months (July-October) and river dominated during the winter and spring (November-June). On 8 November 1983 a transect was made up the estuary beginning $3.9 \mathrm{~km}$ from the mouth at low tide. Surface samples were collected in 51 Niskin bottle and samples for $\mathrm{CO}, \mathrm{CO}-\mathrm{NS}$, and $\mathrm{CH}_{4}$ oxidation were transferred to sterile $500 \mathrm{ml}$ polypropylene bottles, capped and transported to the laboratory in a styrofoam box for analysis. At the time of the sampling the estuary was river dominated (high river flow), as the winter rains had begun. In addition to this transect, single surface water samples were collected from the OSU Marine Science Center dock (approx. $3 \mathrm{~km}$ from the mouth of the estuary) at low tide on the 18 and 19 of October, 1983. These samples were collected in $5 \mathrm{l}$ bottles and returned immediately to the laboratory for analysis.

Carbon monoxide oxidation determinations. The methods used for ${ }^{14} \mathrm{CO}$ preparation and $\mathrm{CO}$ oxidation rate determinations were essentially the same as those 
previously described (Jones and Morita, 1983b). For rate determinations involving pure cultures of methane or ammonium oxidizers, $1.0 \mathrm{ml}$ of the previously described inoculum was used. For soil samples $1.0 \mathrm{~g}$ wet wt was used. The prepared inocula or soils were added to $60 \mathrm{ml}$ serum bottles containing $25 \mathrm{ml}$ of $\mathrm{NH}_{4}^{+}$-free medium adjusted to the proper salinity and $\mathrm{pH}$ (Jones and Morita, 1983a). When natural water samples were used, $25 \mathrm{ml}$ of the sample was placed directly into the serum bottles. The bottles were then purged for 3 min with room air by bubbling it through the liquid using a small aquarium pump, flow was approximately $100 \mathrm{ml} \mathrm{min}{ }^{-1}$. This served to remove dissolved $\mathrm{CO}$ and $\mathrm{CH}_{4}$ in the medium. Since the ambient concentrations of $\mathrm{CO}$ and $\mathrm{CH}_{4}$ in the atmosphere are extremely low compared to that added for the oxidation assays, it was assumed there would be a negligable dilution effect due to ${ }^{12} \mathrm{CO}$ and ${ }^{12} \mathrm{CH}_{4}$ present in the air. The bottles were then sealed with serum stoppers, and $0.5 \mathrm{ml}$ of ${ }^{14} \mathrm{CO}$ diluted in nitrogen was $\left(0.5 \mu \mathrm{Ci} \mathrm{m} l^{-1}\right.$; specific activity, $56 \mathrm{mCi} \mathrm{mmole}^{-1}$; Amersham Corp.) ( $1 \mathrm{mCi}=37 \mathrm{mBq})$ injected into the headspace. All bottles were prepared in triplicate. Acid controls were run with each experiment. Bottles were then incubated for $3 \mathrm{~h}$ (pure cultures and soils), or $12 \mathrm{~h}$ (water samples) on a rotary shaker at $100 \mathrm{rpm}$. Pure cultures of ammonium and methane oxidizers were incubated at $25^{\circ} \mathrm{C}$, soils and Yaquina Bay waters were incubated at $15^{\circ} \mathrm{C}$ (water temperatures ranged from 10.9 to $15.1{ }^{\circ} \mathrm{C}$ at time of collection). Samples from North Coldwater and Spirit Lakes were incubated at $10^{\circ} \mathrm{C}$. Bottles used to determine the NS differential received either $25 \mu \mathrm{l}$ of $100 \mu \mathrm{g} \mathrm{l}^{-1} \mathrm{~N}$-Serve (Chem Services, Westchester, PA) in DMSO or $25 \mu \mathrm{l}$ of DMSO (controls). These bottles were then stoppered as before, but they were preincubated for 1 h on a rotary shaker at $100 \mathrm{rpm}$ at the appropriate temperature before addition of the ${ }^{14} \mathrm{CO}$ and incubated as usual. After incubation, the reaction was terminated by the addition of $1.0 \mathrm{ml}$ of $5.0 \mathrm{~N} \mathrm{NaOH}$ with a syringe through the stopper. The serum bottles were then shaken for $1 \mathrm{~h}$ at room temperature to permit the labeled $\mathrm{CO}_{2}$ to be absorbed into solution. The serum stoppers were then removed and the bottles were shaken an additional $30 \mathrm{~min}$ in an exhaust hood to remove the remaining labeled $\mathrm{CO}$. Labeled $\mathrm{CO}_{2}$ was then released, trapped and assayed using the methods previously described by Griffiths et al. (1982).

Methane oxidation determinations. The procedures used to determine methane oxidation rates were identical to those used for $\mathrm{CO}$ with the following exceptions; once the bottles were sealed with serum stoppers, $1.0 \mathrm{ml}$ of ${ }^{14} \mathrm{CH}_{4}$ diluted in nitrogen, instead of ${ }^{14} \mathrm{CO}$, was injected into the headspace $\left(1.0 \mu \mathrm{Ci} \mathrm{m}{ }^{-1}\right.$; specific activity, $59 \mathrm{mCi} \mathrm{mmole}^{-1}$; Amersham Corp.).
Ammonium oxidizers cultures were incubated for $48 \mathrm{~h}$ rather than $3 \mathrm{~h}$ as with $\mathrm{CO}$, methane oxidizers and field samples were incubated as before.

Chemical analysis. Samples collected at North Coldwater Lake, Spirit Lake and Yaquina Bay were part of ongoing research projects. Analyses of $\mathrm{NH}_{4}^{+}, \mathrm{NO}_{2}^{-}$, and $\mathrm{NO}_{3}^{-}$for North Coldwater and Spirit Lakes were provided by $\mathrm{C}$. Dahm and $\mathrm{NH}_{4}^{+}$and salinity measurements for Yaquina Bay were provided by J. Garber and J. Butler

Ancillary determinations. Water samples collected on October 18 and 19, 1983 at Yaquina Bay were subjected to a series of additional experiments to elucidate factors related to this proposed method.

Time course experiments at one $\mathrm{CO}$ and one $\mathrm{CH}_{4}$ concentration, were conducted both in the presence and absence of $10 \mathrm{mg} \mathrm{l}^{-1} \mathrm{NH}_{4}^{+}-\mathrm{N}$. For $\mathrm{CO}, 3$ series of bottles were prepared ( $60 \mathrm{ml}$ bottles with $25 \mathrm{ml}$ water), one containing $0.5 \mathrm{ml}$ of the ${ }^{14} \mathrm{CO}-\mathrm{N}_{2}$ mixture, another containing $0.5 \mathrm{ml}{ }^{14} \mathrm{CO}-\mathrm{N}_{2}$ and $100 \mathrm{mg} \mathrm{l}^{-1} \mathrm{NS}$ in DMSO, and one with $0.5 \mathrm{ml}{ }^{14} \mathrm{CO}-\mathrm{N}_{2}$ and $10 \mathrm{mg} \mathrm{l}^{-1}$ $\mathrm{NH}_{4}^{+}-\mathrm{N}$ [as $\left(\mathrm{NH}_{4}\right)_{2} \mathrm{SO}_{4}$ ]. At time intervals of $1,3,6,12$, 24 , and 48 and $72 \mathrm{~h}, 3$ bottles from each series were assayed for ${ }^{14} \mathrm{CO}$ oxidized to ${ }^{14} \mathrm{CO}_{2}$. Two series of bottles were prepared for $\mathrm{CH}_{4}$ oxidation, one with $1.0 \mathrm{ml}$ of the ${ }^{14} \mathrm{CH}_{4}-\mathrm{N}_{2}$ mixture and another with $1.0 \mathrm{ml}$ ${ }^{14} \mathrm{CH}_{4}$ and $10 \mathrm{mg} \mathrm{l}^{-1} \mathrm{NH}_{4}^{+}-\mathrm{N}$. At time intervals of 6,12 , $24,48,72,96$ and 102 h, 3 bottles from each series were assayed for ${ }^{14} \mathrm{CH}_{4}$ oxidized to ${ }^{14} \mathrm{CO}_{2}$.

The effects of $\mathrm{CO}$ concentration on $\mathrm{CO}$ oxidation both in the presence and absence of $100 \mathrm{mg} \mathrm{l}^{-1} \mathrm{NS}$ were examined. Bottles were first injected with $0.5 \mathrm{ml}$ of the ${ }^{14} \mathrm{CO}-\mathrm{N}_{2}$ mixture and then additional quantities of unlabeled $\mathrm{CO}$ to give a series of bottles containing between 2.62 and $108.1 \mu \mathrm{l}^{-1}$ of $\mathrm{CO}$ in the headspace. The bottles were incubated $3 \mathrm{~h}$ and assayed as before.

The effect of sample storage on $\mathrm{CO}$ and $\mathrm{CO}-\mathrm{NS}$ oxidation was examined. Once the water sample was collected it was allowed to set in the sample container for $0,3,6$, or $12 \mathrm{~h}$ before being assayed for $\mathrm{CO}$ and $\mathrm{CO}$ NS oxidation in the usual manner.

Calculations. The equilibrium concentrations of $\mathrm{CO}$ and $\mathrm{CH}_{4}$ in solution were determined by multiplying the mixing ratio of $\mathrm{CO}$ or $\mathrm{CH}_{4}$ in the headspace by the appropriate Bunsen solubility coefficient. The Bunsen coefficients depend upon the temperature and salinity of the sample while the mixing ratio is independent of temperature and pressure. Bunsen coefficients were derived from Schmidt (1979) for CO and Yamamoto et al. (1976) for $\mathrm{CH}_{4}$. Differences in both salinity and temperature of incubation were sufficiently large to affect the solubility of $\mathrm{CO}$ and $\mathrm{CH}_{4}$ significantly. These differences were taken into account when calculating oxidation rates.

Methane and $\mathrm{CO}$ oxidation rates given for the pure 
culture experiments were normalized to nmoles $1^{-1}$ $\mathrm{h}^{-1}$ at a cell density of $10^{6} \mathrm{ml}^{-1}$, using the epifluorescent counts of the inoculum and assuming a linear relationship between cell number and activity. Dissolved $\mathrm{CO}$ concentrations were $2.00 \mathrm{nM}$ for the freshwater isolates and $2.23 \mathrm{nM}$ for the marine isolates. $\mathrm{CH}_{4}$ concentrations were $13.80 \mathrm{nM}$ and $11.93 \mathrm{nM}$ for the freshwater and marine isolates, respectively.

For comparative purposes the $\mathrm{CO}$ and $\mathrm{CH}_{4}$ oxidation rates calculated for field samples were normalized to rates at a $\mathrm{CO}$ concentration of $2.23 \mathrm{nM}$ and a $\mathrm{CH}_{4}$ concentration of $11.93 \mathrm{nM}$. These values were chosen since they allow comparison between this work and previous studies (Jones and Morita, 1983a, 1983b). It was assumed that a linear relation exists between $\mathrm{CO}$ and $\mathrm{CH}_{4}$ concentration at these low concentrations and indeed this has been demonstrated (Conrad and Seiler, 1982; Jones and Morita, 1983a, b).

The ratio of $\mathrm{CH}_{4}$ oxidation to $\mathrm{CO}$ oxidation was calculated by dividing the $\mathrm{CH}_{4}$ oxidation rate at 11.93 $\mathrm{nM}$ by the $\mathrm{CO}$ oxidation rate at $2.23 \mathrm{nM}$. When this ratio was calculated for natural samples only the NS inhibited $\mathrm{CO}$ oxidation was considered.

\section{RESULTS}

The $\mathrm{CO}$ and $\mathrm{CH}_{4}$ oxidation rates and $\mathrm{CH}_{4}$ to $\mathrm{CO}$ oxidation ratios for the pure cultures of ammonium and methane oxidizers are given in Table 1 . The values given for the ammonium oxidizers represent the mean values calculated from rates determined for this paper and previous work in our laboratory. The range of these values are given for the $\mathrm{CH}_{4}$ to $\mathrm{CO}$ oxidation ratios. All of the methane oxidizers examined have a much greater ability to oxidize methane than the ammonium oxidizers, even the senescent cells. The most significant result of this experiment is the difference between the $\mathrm{CH}_{4}$ to $\mathrm{CO}$ oxidation ratios for the methane and ammonium oxidizers. While the log phase cells of the methane oxidizers have ratios ranging from 1.11 to 1.87 , the ammonium oxidizers ratios are at least 25 times lower, 0.0007 to 0.0428 . Even the ratios of senescent cells of the methane oxidizers are at least 9 times higher than those for log cells of the ammonium oxidizers.

The CO, CO-NS, and methane oxidation rates of the soil samples along with representative values from Yaquina Bay, Spirit and North Coldwater Lakes are given in Table 2. The percent of the $\mathrm{CO}$ oxidation varied significantly, with the uncultivated soil having the lowest value, $28.2 \%$, and the surface waters of North Coldwater Lake having the highest percentage, $97.3 \%$. While the $\mathrm{CO}$ oxidation rates in the absence of NS for both soils are similar, the values in the presence of NS vary significantly. With the cultivated soil $74.0 \%$ of the CO oxidation is NS inhibited, while only $28.2 \%$ is with the uncultivated soil.

The results of the depth profile of North Coldwater Lake are given in Fig. 1 and Table 3. Ammonium concentration increases from its surface value of $2.0 \mu \mathrm{g} \mathrm{l}^{-1}$ and peaked at $7.0 \mu \mathrm{g} \mathrm{I}^{-1}$ and then decreased to $2.0 \mu \mathrm{g}$

Table 1. Ratios of methane oxidation to carbon monoxide oxidation by methane and ammonium oxidizing bacteria

\begin{tabular}{|c|c|c|c|c|}
\hline Organism & $\begin{array}{l}\text { Culture } \\
\text { conditions }\end{array}$ & $\begin{array}{c}\mathrm{CH}_{4} \text { oxidation } \\
\text { rate } \\
\left.\text { (nmoles } \mathrm{I}^{-1} \mathrm{~h}^{-1}\right)^{\bullet}\end{array}$ & $\begin{array}{c}\text { CO oxidation } \\
\text { rate } \\
\text { (nmoles } l^{-1} \mathrm{~h}^{-1} \text { ) }\end{array}$ & $\begin{array}{c}\text { Ratio } \mathrm{CH}_{4} \\
\text { oxidation to } \\
\text { CO oxidation }\end{array}$ \\
\hline Methylocystis parrus (OBBP) & $\begin{array}{l}\text { Log phase cells } \\
\text { Senescent cells }\end{array}$ & $\begin{array}{l}6.60 \\
0.526\end{array}$ & $\begin{array}{l}3.53 \\
0.910\end{array}$ & $\begin{array}{l}1.87 \\
0.578\end{array}$ \\
\hline Methylosinus trichosporium (OB3B) & $\begin{array}{l}\text { Log phase cells } \\
\text { Senescent cells }\end{array}$ & $\begin{array}{c}19.73 \\
1.127\end{array}$ & $\begin{array}{l}16.46 \\
2.804\end{array}$ & $\begin{array}{l}1.20 \\
0.402\end{array}$ \\
\hline Methylomonas albus (BG8) & $\begin{array}{l}\text { Log phase cells } \\
\text { Senescent cells }\end{array}$ & $\begin{array}{l}5.25 \\
0.178\end{array}$ & $\begin{array}{l}3.59 \\
0.468\end{array}$ & $\begin{array}{l}1.46 \\
0.380\end{array}$ \\
\hline Marine isolate (SA) & $\begin{array}{l}\text { Log phase cells } \\
\text { Senescent cells }\end{array}$ & $\begin{array}{l}6.05 \\
1.033\end{array}$ & $\begin{array}{l}5.44 \\
1.883\end{array}$ & $\begin{array}{l}1.11 \\
0.549\end{array}$ \\
\hline Nitrosomonas europaea & $\begin{array}{l}\mathrm{w} / \mathrm{O} \mathrm{NH}^{+}-\mathrm{N} \\
10 \mathrm{mg} \mathrm{l}^{-1} \mathrm{NH}_{4}^{+}-\mathrm{N}\end{array}$ & $\begin{array}{l}0.0003 \\
0.0134\end{array}$ & $\begin{array}{l}0.422 \\
0.422\end{array}$ & $\begin{array}{l}0.0007 \pm .0003 \\
0.0319 \pm .018\end{array}$ \\
\hline Nitrosomonas sp. (4W30) & $\begin{array}{l}w / 0 \mathrm{NH}_{4}^{+}-\mathrm{N} \\
10 \mathrm{mg} \mathrm{l}^{-1} \mathrm{NH}_{4}^{+}-\mathrm{N}\end{array}$ & $\begin{array}{l}0.0098 \\
0.0504\end{array}$ & $\begin{array}{l}6.423 \\
6.423\end{array}$ & $\begin{array}{l}0.0015 \pm .0005 \\
0.0078 \pm .004\end{array}$ \\
\hline Nitrosococcus oceanus & $\begin{array}{l}\mathrm{w} / 0 \mathrm{NH}^{+}-\mathrm{N} \\
10 \mathrm{mg}^{-1} \mathrm{NH}_{4}^{+}-\mathrm{N}\end{array}$ & $\begin{array}{l}0.0601 \\
0.1052\end{array}$ & $\begin{array}{l}2.456 \\
2.456\end{array}$ & $\begin{array}{l}0.0245 \pm .019 \\
0.0428 \pm .022\end{array}$ \\
\hline
\end{tabular}


Table 2. Carbon monoxide, carbon monoxide oxidation in the presence of $100 \mathrm{mg}^{-1} \mathrm{~N}$-Serve, and methane oxidation by soil, lake and estuarine samples

\begin{tabular}{|c|c|c|c|c|}
\hline Sample & $\begin{array}{l}\text { CO oxidation } \\
\text { rate } \\
\left(\text { nmoles } h^{-1}\right)\end{array}$ & $\begin{array}{c}\text { rate with } \\
100 \mathrm{mg} \mathrm{l}^{-1} \mathrm{~N} \text {-Serve } \\
\left(\text { nmoles } \mathrm{h}^{-1}\right)^{\bullet}\end{array}$ & $\begin{array}{c}\% \text { CO oxidation } \\
\text { inhibited by } \\
100 \mathrm{mg} \mathrm{l}^{-1} \mathrm{~N} \text {-Serve }\end{array}$ & $\begin{array}{c}\mathrm{CH}_{4} \text { oxidation } \\
\text { rate } \\
\left(\text { nmoles } \mathrm{h}^{-1}\right)^{*}\end{array}$ \\
\hline $\begin{array}{l}\text { Soil, uncultivated, meadow } \\
\text { Silverton, OR }\end{array}$ & 0.305 & 0.219 & 28.2 & 0.0096 \\
\hline $\begin{array}{l}\text { Soil, cultivated, garden } \\
\text { Silverton, OR }\end{array}$ & 0.277 & 0.072 & 74.0 & 0.0003 \\
\hline $\begin{array}{l}\text { Water, North Coldwater Lake, } \\
\text { surface, Mt. St. Helens, WA }\end{array}$ & 0.075 & 0.002 & 97.3 & 0.0001 \\
\hline $\begin{array}{l}\text { Water, Spirit Lake, surface, } \\
\text { Mt. St. Helens, WA }\end{array}$ & 0.297 & 0.102 & 65.7 & 0.0377 \\
\hline $\begin{array}{l}\text { Water, Yaquina Bay, surface, } \\
\text { salinity } 33 \% \text {, Newport, OR }\end{array}$ & 0.136 & 0.018 & 88.5 & 0.0006 \\
\hline $\begin{array}{l}\text { Water, Yaquina Bay, surface, } \\
\text { salinity } 2.2 \% \text {, Newport, OR }\end{array}$ & 1.144 & 0.357 & 68.8 & 0.0144 \\
\hline
\end{tabular}

$\mathrm{l}^{-1}$ and remained constant to $40 \mathrm{~m}$. Nitrite remained constant at $3.0 \mu \mathrm{g} \mathrm{l}^{-1}$ throughout the depth profile, while nitrate decreased steadily through the first $20 \mathrm{~m}$ and then held relatively constant through $40 \mathrm{~m}$. CO oxidation inhibited by NS and $\mathrm{CH}_{4}$ oxidation peaked at $10 \mathrm{~m}$ with values of $0.143 \mathrm{nmoles} \mathrm{l}^{-1} \mathrm{~h}^{-1}$ and 0.008 nmoles $\mathrm{l}^{-1} \mathrm{~h}^{-1}$ respectively (Fig. 1B). CO oxidation inhibited by NS dropped to 0.65 nmoles $\mathrm{l}^{-1} \mathrm{~h}^{-1}$ at $15 \mathrm{~m}$ and then remained essentially constant throughout the profile. The ratios of $\mathrm{CH}_{4}$ oxidation (at $11.93 \mathrm{nM}$ ) to $\mathrm{CO}$
Fig. 1. North Coldwater Lake profile, 18 July 1983. (A) Inorganic nitrogen distribution; $O \mathrm{NH}_{4}^{+}-\mathrm{N}_{i}$ $\mathrm{NO}_{2}^{-}-\mathrm{N}_{;} \square \mathrm{NO}_{3}^{-}-\mathrm{N}$. (B) $\mathrm{CO}$ and $\mathrm{CH}_{4}$ oxidation; O N-Serve inhibited $\mathrm{CO}$ oxidation; $\bullet \mathrm{CO}$ oxidation not inhibited by $\mathrm{N}$-Serve; $\square$ $\mathrm{CH}_{4}$ oxidation
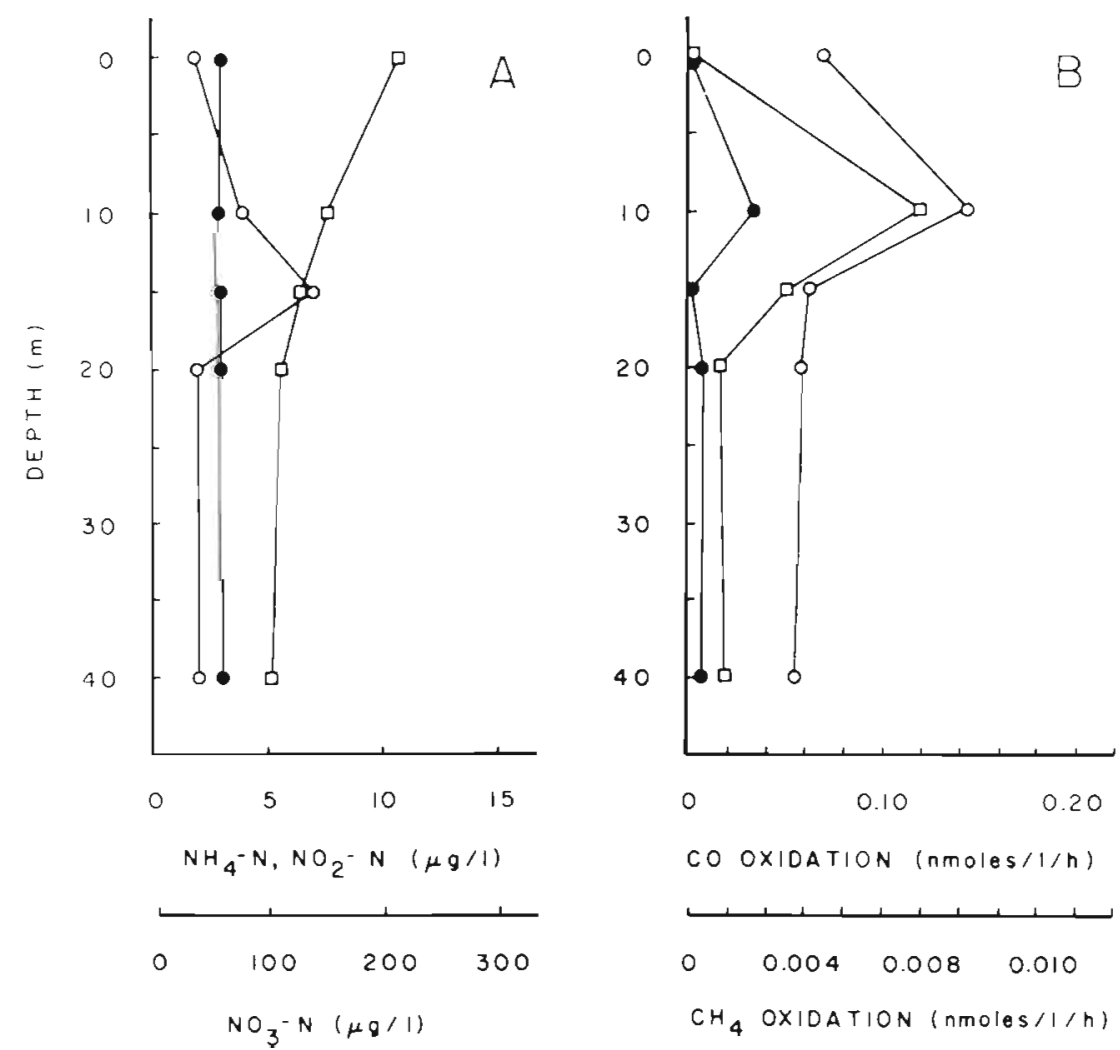
Table 3. Ratios of methane oxidation to carbon monoxide oxidation for North Coldwater and Spirit Lakes

\begin{tabular}{|lcc|}
\hline \multicolumn{1}{|c}{ Sample site } & $\begin{array}{c}\text { Depth } \\
(\mathrm{m})\end{array}$ & $\begin{array}{c}\text { Ratio } \mathrm{CH}_{4} \\
\text { oxidation to } \\
\text { CO oxidation }\end{array}$ \\
\hline North Coldwater Lake & 0 & 0.001 \\
18 July, 1983 & 10 & 0.056 \\
& 15 & 0.052 \\
& 20 & 0.019 \\
Spirit Lake & 40 & 0.022 \\
19 July, 1983 & 0 & 0.262 \\
& 10 & 0.508 \\
& 15 & 0.477 \\
& 25 & 1.292 \\
& 40 & 0.934 \\
\hline
\end{tabular}

oxidation (at 2.23 nM) range from 0.001 at the surface to 0.056 at $10 \mathrm{~m}$ (Table 3 ).

Spirit Lake had a considerably different profile (Fig. 2). Ammonium decreased steadily from a surface high of $5 \mu \mathrm{g} \mathrm{l}^{-1}$ to undetectable values at $25 \mathrm{~m}$. Nitrite as before was essentially constant throughout the water column at $2 \mu \mathrm{g} \mathrm{l}^{-1}$. Nitrate decreased rapidly from 0 to $25 \mathrm{~m}$ and then increased at $40 \mathrm{~m}$. CO oxidation inhibited by $\mathrm{NS}$ and $\mathrm{CH}_{4}$ oxidation values were high throughout the water column (Fig. 2B). CO oxidation inhibited by NS peaked at $15 \mathrm{~m}$ and $40 \mathrm{~m}$ with values of 0.409 nmoles $1^{-1} \mathrm{~h}^{-1}$ and 0.460 nmoles $l^{-1} \mathrm{~h}^{-1}$ respectively. The ratios of $\mathrm{CH}_{4}$ oxidation to $\mathrm{CO}$ oxidation were considerably higher than those for North
Coldwater Lake and ranged from 0.262 at the surface to 1.292 at $25 \mathrm{~m}$ (Table 3 ).

The results of the Yaquina Bay transect are shown in Fig. 3. CO oxidation inhibited by NS increased steadily, peaked, decreased slightly, leveled off and then peaked again at the last station. This final peak was likely due to terrestrial input, as this station was nearly freshwater and was sampled just after a record rainfall. Ammonium nitrogen also increased peaked and then decreased progressively up river, with the peak at 8.5 to $10.5 \mathrm{~km}$ (Fig. 3). Methane oxidation increased steadility up river over the entire length of the transect (Fig. 3). The ratio of $\mathrm{CH}_{4}$ oxidation to $\mathrm{CO}$ oxidation remained low with values ranging from 0.005 for the incoming ocean water and 0.018 for the $2.6 \%$ water at the station furthest upstream (Table 4).

The results of the time course of $\mathrm{CO}$ oxidation experiments are shown in Fig. 4. The oxidation of $\mathrm{CO}$ in the absence of added $\mathrm{NH}_{4}^{+}-\mathrm{N}$ was linear through $48 \mathrm{~h}$ and then increased rapidly. In the presence of $10 \mathrm{mg} \mathrm{l}^{-1}$ $\mathrm{NH}_{4}^{+}-\mathrm{N}$, CO oxidation paralleled that without ammonium added for $24 \mathrm{~h}$ and then increased rapidly. CO oxidation in the presence of $100 \mathrm{mg} \mathrm{l}^{-1} \mathrm{NS}$ was linear through $6 \mathrm{~h}$ and then decreased through $72 \mathrm{~h}$.

The time course of $\mathrm{CH}_{4}$ oxidation both in the presence and absence of added $\mathrm{NH}_{4}^{+}-\mathrm{N}$ were essentially linear through the first $48 \mathrm{~h}$ and then decreased through $120 \mathrm{~h}$ (Fig. 5). Ammonium nitrogen had little effect on $\mathrm{CH}_{4}$ oxidation.

The relation between $\mathrm{CO}$ concentration and $\mathrm{CO}$ oxidation both in the presence and absence of $100 \mathrm{mg} \mathrm{l}^{-1}$

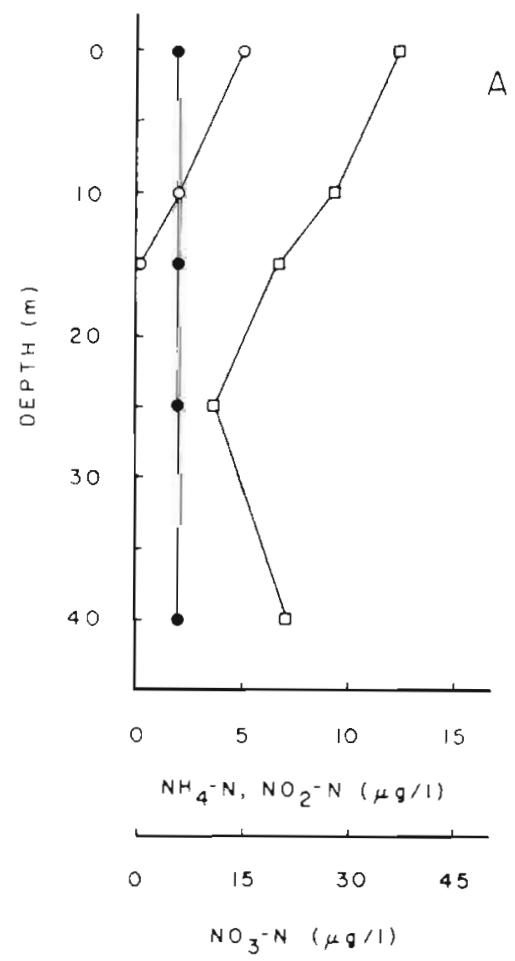

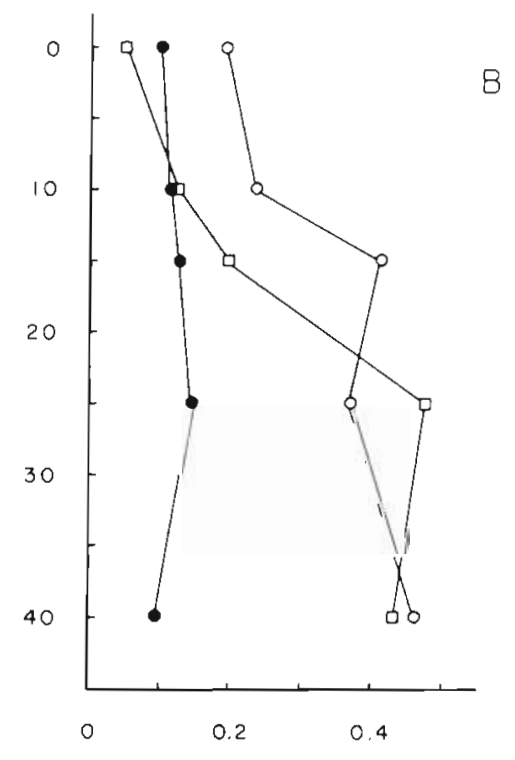

CO AND CH 4 OXIOATION (nmoles/I/n)
Fig. 2. Spirit Lake profile, 19 July 1983. (A) Inorganic nitrogen distribution; $O \mathrm{NH}_{4}^{+}-\mathrm{N}_{i} \bullet \mathrm{NO}_{2}^{-}-\mathrm{N}$. (B) $\mathrm{CO}$ and $\mathrm{CH}_{4}$ oxidation; $\mathrm{ON}$-Serve inhibited $\mathrm{CO}$ oxidation; $\bullet \mathrm{CO}$ oxidation not inhibited by N-Serve; $\square$ $\mathrm{CH}_{4}$ oxidation 
Fig. 3. Yaquina Bay transect, 8 Nov, 1983. O N-Serve inhibited $\mathrm{CO}$ oxidation; $\bullet \mathrm{CO}$ oxidation not inhibited by $\mathrm{N}$ Serve; $\square \mathrm{NH}_{4}^{+}-\mathrm{N}$ concentration; salinity: $\triangle \mathrm{CH}_{4}$ oxidation

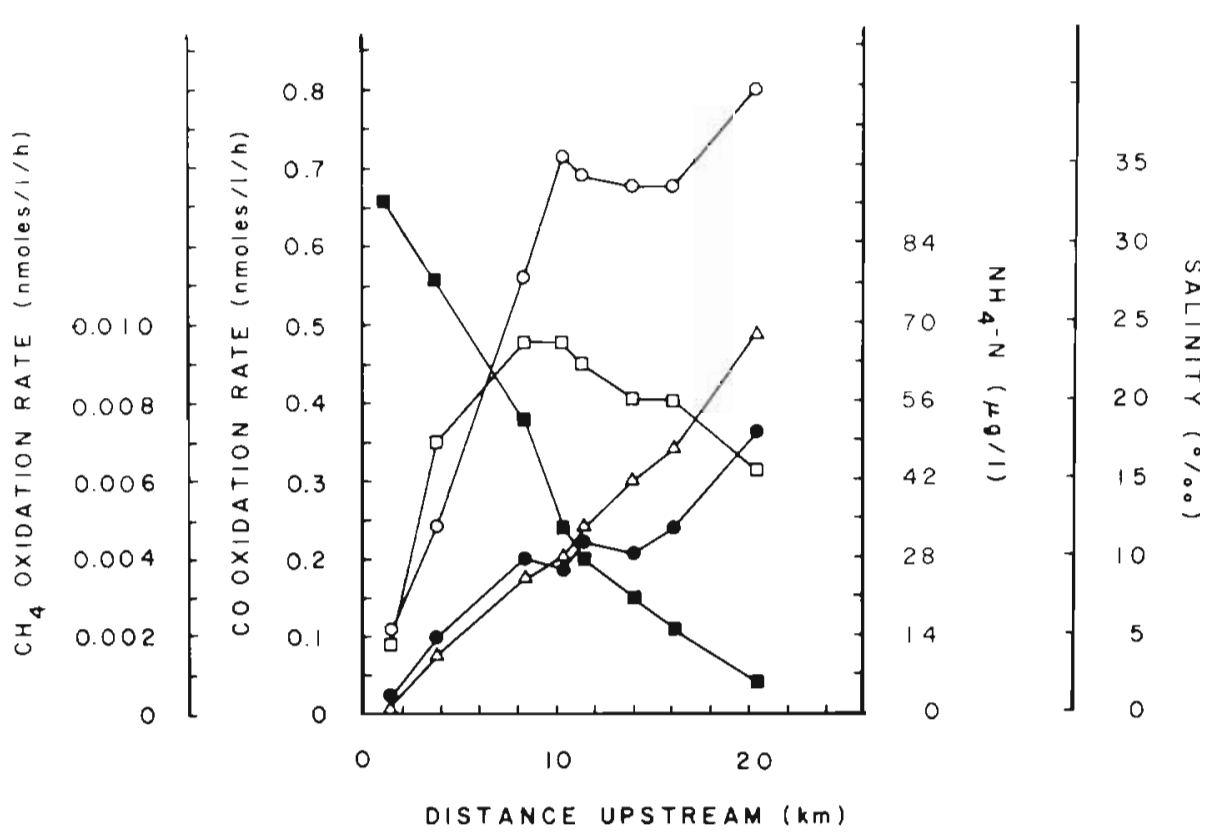

cally. Among these are the carboxydobacteria (Zavarzin and Nozhevnikova, 1977), several actinomycetes (Bartholomew and Alexander, 1979), the methane oxidizing bacteria (Ferenci, 1974; Hubley et al., 1974; Ferenci et al., 1975), and the chemolithotrophic ammonium oxidizers (Jones and Morita, 1983b). It is likely that all of these organisms and others yet to be discovered play a role in the oxidation of $\mathrm{CO}$ in the

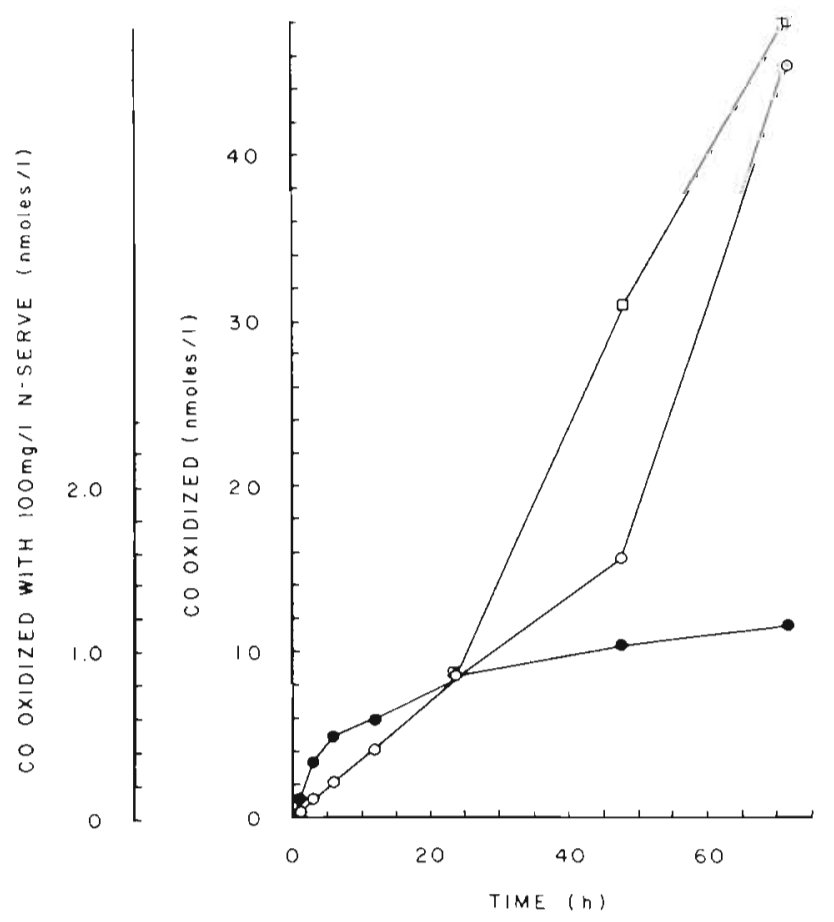

Fig. 4. Time course of $\mathrm{CO}$ oxidation by a Yaquina Bay water sample. $\bigcirc$ no additions; $100 \mathrm{mg} \mathrm{l}^{-1} \mathrm{~N}$-Serve; $\square 10 \mathrm{mg} \mathrm{l}^{-1}$ $\mathrm{NH}_{4}^{+}-\mathrm{N}$ 


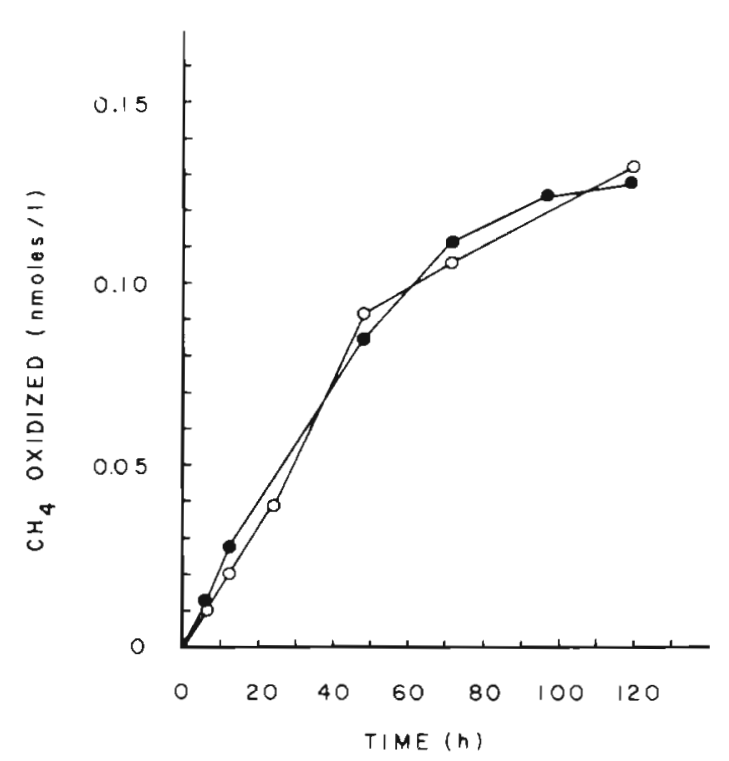

Fig. 5. Time course of $\mathrm{CH}_{4}$ oxidation by Yaquina Bay water sample. $O$ no additions; $10 \mathrm{mg} \mathrm{l}^{-1} \mathrm{NH}_{4}^{+}-\mathrm{N}$

environment. The results of this study and previous studies would seem to indicate that the ammonium oxidizers could play an important role in $\mathrm{CO}$ oxidation in the environment (Jones and Morita, 1983b). It has been demonstrated by Conrad et al. (1981) and Conrad and Seiler (1982) that the carboxydobacteria do not play a major role in the oxidation of $\mathrm{CO}$ in the soils, oceans or lakes. This is evidenced by their high $\mathrm{Km}$ values (390 to $930 \mathrm{nM}$ ) (Conrd et al., 1981) and the low values of incorporation of ${ }^{14} \mathrm{CO}-\mathrm{C}$ into cellular material found by Bartholomew and Alexander (1979) for soils. This paper presents additional support for this in that $\mathrm{Km}$ values for Yaquina Bay waters ranged from 8 to $42 \mathrm{nM}$, well below those for the carboxydobacteria. In addition to this no incorporation of ${ }^{14} \mathrm{CO}-\mathrm{C}$ was detected in Yaquina Bay waters (Jones and Morita, unpubl.).

$\mathrm{N}$-Serve is a powerful inhibitor of chemolithotrophic nitrification (Goring, 1962) and has been used previously for estimating nitrification rates (Webb and Wiebe, 1975; Christofi et al., 1981; Hall, 1982). Jones and Morita (ms submitted) have demonstrated that NS can also be used to inhibit the oxidation of $\mathrm{CO}$ by ammonium oxidizers. $\mathrm{CO}$ oxidizers can be divided into two groups using NS inhibition, those that are inhibited and those that are not inhibited by NS. The relative proportion of these groups can vary significantly (Table 2) and is not necessarily related to the total $\mathrm{CO}$ oxidation rate. The best examples of this are the 2 soil types examined for this study. While both soil types have high $\mathrm{CO}$ oxidation rates in the absence of NS, in the uncultivated soil only $28.2 \%$ of the CO
Table 5. Calculated ammonium oxidation rates for North Coldwater Lake and Yaquina Bay

\begin{tabular}{|cc|cc|}
\hline $\begin{array}{c}\text { North Coldwater Lake } \\
\text { Depth } \\
(\mathrm{m})\end{array}$ & $\begin{array}{c}\text { Yate } \\
(\text { nmoles } \\
\left.\mathrm{l}^{-1} \mathrm{~h}^{-1}\right)\end{array}$ & $\begin{array}{c}\text { Yaquina } \\
\text { Distance } \\
\text { upstream } \\
(\mathrm{km})\end{array}$ & $\begin{array}{c}\text { Rate } \\
(\text { nmoles } \\
\left.\mathrm{I}^{-1} \mathrm{~h}^{-1}\right)\end{array}$ \\
\hline 0 & 0.39 & 1.5 & 4.06 \\
10 & 1.55 & 3.9 & 32.20 \\
15 & 1.23 & 8.5 & 101.50 \\
20 & 0.32 & 10.5 & 129.36 \\
25 & 0.30 & 11.4 & 117.32 \\
& & 14.2 & 103.88 \\
& & 16.2 & 104.16 \\
& & 20.3 & 94.22 \\
\hline
\end{tabular}

Table 6. North Coldwater Lake and Yaquina Bay nitrification rates compared to other waters

\begin{tabular}{|c|c|c|}
\hline Locality & $\begin{array}{c}\text { Rate } \\
\text { (nmoles } \\
\mathrm{l}^{-1} h^{-1} \text { ) }\end{array}$ & Reference \\
\hline Lake Vanda & $0.25-5.8$ & Vincent et al. (1981) \\
\hline Lake Taupo & $1.5-1.2$ & $\begin{array}{l}\text { Vincent and Downes } \\
\text { (1981) }\end{array}$ \\
\hline Lake Mendota & $2-44$ & Brezonik (1968") \\
\hline Belelham Tarn & 134 & Christofi et al. (1981) \\
\hline North Coldwater Lake & $0.39-1.55$ & This work \\
\hline Scheldt Estuary & $170-490$ & Somville (1978) \\
\hline $\begin{array}{l}\text { Scheldt Estuary } \\
\text { (potential) }\end{array}$ & $50-1700$ & Somville (1978) \\
\hline Sagami Bay & $0.16-5.0$ & Miyazaki et al. (1973) \\
\hline $\begin{array}{l}\text { California coastal } \\
\text { waters }\end{array}$ & $0.67-1.67$ & Ward et al. (1982) \\
\hline Yaquina Bay & $4,06-129$ & This work \\
\hline
\end{tabular}

oxidation was inhibited by NS, while $74.0 \%$ of the activity was NS inhibited with the garden soil. At the same time the uncultivated soil had MPN values of $1.7 \times 10^{5}$ ammonium oxidizers $\mathrm{g} \mathrm{dry} \mathrm{wt}^{-1}$ while the garden soil contained $2.4 \times 10^{6} \mathrm{~g} \mathrm{dry} \mathrm{wt}^{-1}$ (Jones and Morita, unpubl.). The Km values for Yaquina Bay also demonstrate that there are 2 separate nonrelated groups. While the NS inhibited group had a $\mathrm{Km}$ value of $42.0 \mathrm{nM}$ and a Vmax of 5.0 nmoles $\mathrm{l}^{-1} \mathrm{~h}^{-1}$, the noninhibited group had a $\mathrm{Km}$ of $8.1 \mathrm{nM}$ and a Vmax of 0.26 nmoles $\mathrm{l}^{-1} \mathrm{~h}^{-1}$. In addition, none of the Lineweaver-Burke plots were parallel or shared either $\mathrm{Km}$ or Vmax values. This demonstrates that the group that was not inhibited by NS does not simply represent competitive, noncompetitive or uncompetitive inhibition of the NS inhibited group. The oxidation of methane by the methane oxidizers has also been 
demonstrated to be inhibited by NS (Topp and Knowles, 1982).

Studies in our laboratory have shown that CO oxidation by the methane oxidizers is also completely inhibited by $100 \mathrm{mg} \mathrm{l}^{-1}$ NS (Jones and Morita, unpubl.). Although it is possible that there are other organisms involved in the NS sensitive oxidation of $\mathrm{CO}$ at the present time, it seems likely that this group contains mainly the ammonium and methane oxidizers. Because of these findings it is necessary to distinguish between the ammonium and methane oxidizers. Since both methane and ammonium oxidizers oxidize methane (Jones and Morita, 1983a) and CO, the ratios of $\mathrm{CH}_{4}$ to $\mathrm{CO}$ oxidation provide this distinction. While the methane oxidizers had values of between 0.380 for senescent cells of Methylomonas albus (B68) to 1.87 for log cells Methylocystis parvus (OBBP), the ammonium oxidizer values were much smaller, 0.0007 for Nitrosomonas europaea in the absence of $\mathrm{NH}_{4}-\mathrm{N}$ to 0.0428 for Nitrosococcus oceanus in the presence of $10 \mathrm{mg} \mathrm{l}^{-1}$ $\mathrm{NH}_{4}^{+}-\mathrm{N}$ (Table 1). The depth profiles from North Coldwater and Spirit Lakes demonstrate that this distinction holds for environmental samples. While North Coldwater Lake is an ammonium oxidizer dominated systems (ratios of 0.001 to 0.056 ) Spirit Lake is a methane oxidizer dominated system with ratios ranging from 0.262 to 1.292 (Table 3 ). The values for the soil samples and estuarine water samples show they are also dominated by ammonium oxidizers (Tables 2 and 4). In situations where the ratios are high $(>0.2)$, it becomes difficult to determine how much of the $\mathrm{CO}$ oxidation is due to ammonium oxidizers, and from the viewpoint of this method it will work best where the system is ammonium oxidizer dominated, unless ammonium oxidation rates for the methane oxidizers are determined. The use of these ratios will, however, allow distinction between these 2 types of systems. In a paper dealing with methane oxidation in Lake Mendota (Wisconsin), Harrits and Hanson (1980) demonstrate that ammonium oxidation closely parallels the rates of methane oxidation, and suggest that since methane oxidizers are known to oxidize ammonium (Whittenbury et al., 1970; O'Neill and Wilkinson, 1979) they may contribute to the nitrogen cycle in Lake Mendota. Jones and Morita (1983a) suggest that an alternative explanation for this may be methane oxidation by the classical ammonium oxidizers. The results of the present study provide a method of determining the answer to this question

Although ammonium oxidation by the chemolithotrophic ammonium oxidizers is considered to be important in the cycle of nitrogen in the oceans, freshwaters and soils, to date there is not a simple, sensitive or rapid technique to assay their importance. The procedure developed in this paper offers several advantages over existing methods for determining ammonium oxidation. First, the sample size necessary is small, the present study uses $25 \mathrm{ml}$ samples. Second, the incubation time necessary to get results is short, 3 to $12 \mathrm{~h}$. Third, it is not necessary to add abnormally high $\mathrm{NH}_{4}^{+}$ concentrations to obtain results. Finally, the use of ${ }^{14} \mathrm{CO}$ as an alternative substrate for the chemolithotrophic ammonium oxidizers offers much greater sensitivity than the use of nonradiolabeled substrates. In addition to this, sensitivity can be increased by either increasing the sample size or increasing the ${ }^{14} \mathrm{CO}$ concentration.

In order for this method to be most accurate several factors must be taken into consideration, (1) the blockage of $\mathrm{CO}$ oxidation by NS must be complete, (2) the oxidation of $\mathrm{CO}$ and $\mathrm{CH}_{4}$ must be linear with respect to both time of incubation and concentration, and (3) the ammonium oxidizers rather than the methane oxidizers must be the major group responsible for the NS inhibited $\mathrm{CO}$ oxidation.

The blockage of CO oxidation by ammonium oxidizers has been demonstrated to be complete with $100 \mathrm{mg}$ $\mathrm{l}^{-1}$ added NS (Jones and Morita, ms submitted). In addition, studies with soils and Yaquina Bay waters show that increasing NS concentrations beyond $100 \mathrm{mg} \mathrm{l}^{-1}$ causes no additional decrease in CO oxidation (Jones and Morita, unpubl.).

The results of this study with respect to time of incubation and $\mathrm{CO}$ oxidation (Fig. 4) indicate that while CO oxidation in the presence of NS loses linearity after 3 to $6 \mathrm{~h}$, its deviation from linearity is not great enough to cause significant changes in the results when samples are incubated for $12 \mathrm{~h}$, but it would be advisable that future studies use incubation times of $6 \mathrm{~h}$ or less, $\mathrm{CO}$ oxidation in the absence of NS was linear for $48 \mathrm{~h}$ and therefore presents no problem. Methane oxidation rates from this study (Fig. 5) and in that of Griffiths et al. (1982), show that methane oxidation is linear with time through $48 \mathrm{~h}$. The effects of increasing $\mathrm{CO}$ concentrations have been shown to be linear in this study and in those of Jones and Morita (1983a) and Conrad and Seiler (1982).

It may be possible to convert the rate of CO oxidation inhibited by NS to a rate of ammonium oxidation if the in situ concentrations of ammonium are known. Since $\mathrm{CO}$ acts as an alternative substrate for the ammonium monooxygenase system (Tsang and Suzuki, 1982; Jones and Morita, 1983a) and since there is no transport mechanism necessary for $\mathrm{CO}$, the oxidation of $\mathrm{CO}$ should act as a sensitive enzyme assay for ammonium monooxygenase activity. It is interesting to use the values of ammonium oxidation at $1.0 \mathrm{mg} \mathrm{l} \mathrm{m}^{-1} \mathrm{NH}_{4}^{+}-\mathrm{N}$ reported by Jones and Morita (in press) for the ammonium oxidizers, Nitrosomonas europaea oxidized $1.2 \mu$ moles $\mathrm{NH}_{4}^{+} \mathrm{l}^{-1} \mathrm{~h}^{-1}$ at $10^{6}$ cells $l^{-1} ; \mathrm{Ni}_{\text {- }}$ 
trosomonas sp. $4 \mathrm{~W} 30$ oxidized $21 \mu$ moles $\mathrm{NH}_{4}^{+} \mathrm{l}^{-1} \mathrm{~h}^{-1}$, and Nitrosococcus oceanus oxidized 5.8 umoles $\mathrm{NH}_{4}^{+} \mathrm{l}^{-1} \mathrm{~h}^{-1}$, and the $\mathrm{CO}$ oxidation rates reported in this paper (Table 1) ( $N$. europaea at $2.23 \mathrm{nM} \mathrm{CO}$ gives an oxidation rate of 0.471 nmoles $\mathrm{l}^{-1} \mathrm{~h}^{-1}$ ) to calculate a ratio of $\mathrm{CO}$ oxidized at $2.23 \mathrm{nMCO}$ to $\mathrm{NH}_{4}^{+}-\mathrm{N}$ oxidized at $1.0 \mathrm{mg} \mathrm{l}^{-1}$. These ratios are $3.9 \times 10^{-4}$ for $N$. europaea, $3.1 \times 10^{-4}$ for Nitrosomonas sp. 4 W30, $4.2 \times$ $10^{-4}$ for $N$. oceanus, with an average value of $3.7 \times 10^{-4}$. Using this value, assuming linearity (first order kinetics) for ammonium concentrations of $<1.0 \mathrm{mg} \mathrm{l^{-1 }} \mathrm{NH}_{4}^{+}-\mathrm{N}$, knowing the in situ concentrations of $\mathrm{NH}_{4}^{+}-\mathrm{N}_{1}$ and value for $\mathrm{NS}$ inhibited to $\mathrm{CO}$ oxidation, an actual rate can be calculated. Ammonium oxidation rates calculated from these data are given in Table 5 . These values are within the range of activity reported by other workers (Table 6). It would be interesting to correlate these with actual field determinations of $\mathrm{NH}_{4}^{+}$oxidation using ${ }^{15} \mathrm{~N}$ tracer methodologies to determine if the $\mathrm{NH}_{4}^{+}$to $\mathrm{CO}$ oxidation ratios hold in natural samples. The NS inhibited CO oxidation rates (and calculated ammonium oxidation rates) follow the ammonium concentration in Yaquina Bay (Fig. 3). The NS inhibited $\mathrm{CO}$ oxidation gives a potential ammonium oxidation that reflects the activity at the in situ temperature, $\mathrm{pH}$ and salinity and the calculated rates of ammonium oxidation would therefore represent actual in situ rates.

The method for determining in situ ammonium oxidation developed here can be applied to all types of environmental samples, soils, freshwaters and ocean waters. The determinations are performed over short time frames ( 3 to $12 \mathrm{~h}$ ) and have lower detection limits than any other method currently in use, 0.0008 nmoles $\mathrm{l}^{-1} \mathrm{~h}^{-1}{ }^{14} \mathrm{CO}$ oxidized to $\mathrm{CO}_{2}$ with $25 \mathrm{ml}$ samples or 0.0004 nmoles $\mathrm{l}^{-1} \mathrm{~h}^{-1}$ with $50 \mathrm{ml}$ samples. These would translate to ammonium oxidation rates of $2.2 \times 10^{-4}$ nmoles $\mathrm{NH}_{4}^{+}$oxidized $\mathrm{l}^{-1} \mathrm{~h}^{-1}$ and $1.1 \times 10^{-4}$ nmoles $\mathrm{l}^{-1}$ $\mathrm{h}^{-1}$ at $\mathrm{NH}_{4}^{+}$concentrations of $0.1 \mu \mathrm{gl}^{-1}$. The use of this method may allow the determination of ammonium oxidation in the environments where it was previously impossible to obtain such estimates. It should also simplify the determinations in other samples such as soils, estuarine waters, eutrophic lake and river waters, and coastal ocean waters.

Acknowledgements. We thank J. Garber and J. Butler for providing the opportunity to sample Yaquina Bay; C. Dahm for the opportunity to sample North Coldwater and Spirit Lakes; and A. Dietrich for providing the soil samples. We also thank Liz Jones for preparing the figures. This paper is based on research supported by National Science Foundation grant OCE 8108366 . R. Jones was supported in part by a N. L. Tartar Research Fellowship.

\section{LITERATURE CITED}

Baross, J. A., Dahm, C. N., Ward, A. K., Lilley, M. D., Sedell, J. R. (1982). Initial rnicrobiological response in lakes to the Mt. St. Helens eruption. Nature, Lond. 296: 49-52

Bartholomew, G., Alexander, M. (1979). Metabolism of carbon monoxide in culture and in soil. Appl. environ. Microbiol. 37. 932-937

Belser, L. W. (1979). Population ecology of nitrifying bacteria. A. Rev. Microbiol. 33: 309-333

Belser, L. W., Mays, E. L. (1980). Specific inhibition of nitrite oxidation by chlorate and its use in assessing nitrification in soils and sediments. Appl. environ. Microbiol. 39: 505-510

Belser, L. W., Mays, E. L. (1982). Use of nitrifier activity measurements to estimate the efficiency of viable nitrifier counts in soil and sediments. Appl, environ. Microbiol. 43 : 945-948

Bendschneider, K., Robinson, R. J. (1952). A new spectrophotometric method for the determination of nitrite in seawater. J. mar. Res. 11: 87-96

Billen, G. (1975). Nitrification in the Scheldt Estuary (Belgium and the Netherlands). Estuar. coast. mar. Sci. 3: 79-89

Billen, G. (1976). Evaluation of nitrifying activity in sediments by dark ${ }^{14} \mathrm{C}$-bicarbonate incorporation. Wat. Res. 10: $51-57$

Carlucci, A. F., Strickland, J. D. H. (1968). The isolation, purification and some kinetic studies of marine nitrifying bacteria. J. exp. mar. Biol. Ecol. 2: 156-166

Christofi, N., Preston, T., Stewart, W. D. P. (1981). Endogenous nitrite production in an experimental enclosure during summer stratification. Wat. Res. 15: 343-349

Conrad, R., Seiler, W. (1982). Utilization of traces of carbon monoxide by aerobic oligotrophic microorganisms in ocean, lake and soil. Arch. Mikrobiol. 132: 41-46

Conrad, R., Meyer, O., Seiler, W (1981). Role of carboxydobacteria in consumption of atmospheric carbon monoxide by soil. Appl. environ. Microbiol. 42: 211-215

Dugdale, R. C., Goering, J. J. (1967). Uptake of new and regenerated forms of nitrogen in primary productivity Limnol. Oceanogr. 12: 196-206

Ferenci, T (1974). Carbon monoxide-stimulated respiration in methane-utilizing bacteria. FEBS Lett. 41: 94-98

Ferenci, T., Strom, T., Quayle, J. R. (1975). Oxidation of carbon monoxide and methane by Pseudomonas methanica. J. gen. Microbiol. 91: 79-91

Goring, C. A. I. (1962). Control of nitrification by 2-chloro-6(trichloromethyl)pyridine. Soil Sci. 93: 211-218

Griffiths, R. P., Caldwell, B. A., Cline, J. D., Broich, W. A., Morita, R. Y. (1982). Field observations of methane concentrations and oxidation rates in the southeastern Bering Sea. Appl. environ. Microbiol. 44: 435-446

Hall, G. H. (1982). Apparent and measured rates of nitrification in the hypolimnion of a mesotrophic lake. Appl. environ. Microbiol. 43: 542-547

Harrits, S. M., Hanson, R. S. (1980). Stratification of aerobic methane-oxidizing organisms in Lake Mendota, Madison, Wisconsin. Limnol. Oceanogr. 25: 412-421

Hobbie, J. E., Daley, R. J., Jasper, S. (1977). Use of Nucleopore filters for counting bacteria by fluorescent microscopy. Appl. environ. Microbiol. 33: 1225-1228

Hubley, J. H., Mitton, J. R., Wilkinson, J. F. (1974). The oxidation of carbon monoxide by methane-oxidizing bacteria. Arch. Mikrobiol. 95: 365-368

Hyman, M. R., Wood, P. M. (1983). Methane oxidation by Nitrosomonas europaea. Biochem. J. 212: 31-37 
Hynes, R. K., Knowles, R. (1983). Inhibition of chemoautotrophic nitrification by sodium chlorate and sodium chlorite: a reexamination. Appl. environ. Microbiol. 54: $1178-1182$

Jones, R. D., Morita, R. Y. (1983a). Methane oxidation Nitrosococcus oceanus and Nitrosomonas europaea. Appl. environ. Microbiol. 45; 401-410

Jones, R. D., Morita, R. Y (1983b). Carbon monoxide oxidation by chemolithotrophic ammonium oxidizers. Can. J. Microbiol. 29: 1545-1551

Jones, R. D., Morita, R. Y. (1984). Effects of various parameters on carbon monoxide oxidation by ammonium oxidizers. Can. J. Microbiol. (in press)

Jones, R. D., Morita, R. Y. Effects of several nitrification inhibitors on carbon monoxide and methane oxidation by ammonium oxidizers. Can. J. Microbiol. (manuscript submitted)

Miyazaki, M., Wada, E., Hattori, A. (1973). Capacities of shallow waters of Sagami Bay for oxidation and reduction of inorganic nitrogen. Deep Sea Res. 20: 571-577

Ohmori, M., Iizumi, H., Hattori, A. (1981). An improved procedure for ${ }^{15} \mathrm{~N}$ determination by emission spectrometry. Analyt. Biochem. 111: 83-96

O'Neill, J. G., Wilkinson, J. F. (1977). Oxidation of ammonia by methane-oxidizing bacteria end the effects of ammonia on methane oxidation. J. gen. Microbiol. 100: 407-412

Schmidt, U. (1979). The solubility of carbon monoxide and hydrogen in water and sea-water at partial pressures of about $10^{-5}$ atmospheres. Tellus 31: 68-74

Schwert, D. P., White, J. P. (1974). Method for in situ measurement of nitrification in a stream. Appl. environ. Microbiol. 28: $1082-1083$

Somville, M. (1978). A method for the measurement of nitrification rates in water. Wat. Res. 12: 843-848
Topp, E., Knowles, R. (1982). Nitrapyrin inhibits the obligate methyltrophs Methylosinus trichosporium and Methylococcus capsulatus. FEMS Microbiol. Lett. 14: 47-49

Tsang, D. C. Y., Suzuki, I. (1982). Cytochrome $C_{553}$ as a possible electron donor in the hydroxylation of ammonium and carbon monoxide in Nitrosomonas europaea. Can. J. Biochem. 60: 1018-1024

Vincent, W. F., Downes, M. T (1981). Nitrate accumulation in aerobic hypolimnia: relative importance of benthic and planktonic nitrifiers in an oligotrophic lake. Appl. environ. Microbiol. 42: 565-573

Vincent, W. F., Downes, M. T., Vincent, C. L. (1981). Nitrous oxide cycling in Lake Vanda, Antarctica. Nature, Lond. 292: 618-620

Wada, E., Tsuji, T., Saino, T., Hattori, A. (1977). A simple procedure for mass spectrometric microanalysis of ${ }^{15} \mathrm{~N}$ in particulate organic matter with special reference to ${ }^{15} \mathrm{~N}$ tracer experiments. Analyt. Biochem. 80: 312-318

Ward, B. B., Olson, R. J., Perry, M. J. (1982). Microbial nitrification rates in the primary nitrite maximum off southern California. Deep Sea Res. 29: 247-255

Watson, S. W. (1965). Characteristics of a marine nitrifying bacterium, Nitrosocystis oceanus sp. n. Limnol. Oceanogr. 10: R274-R289

Webb, K. L., Wiebe, W. J. (1975). Nitrification on a coral reef. Can. J. Microbiol. 21: 1427-1431

Whittenbury, R., Phillips, K. C., Wilkinson, J. F. (1970). Enrichment, isolation and some properties of methaneutilizing bacteria. J. gen. Microbiol. 61: 205-218

Yamamoto, S., Alcauskas, J. B., Crotier, T. C. (1976). Solubility of methane in distilled water and seawater. J. Chem. Eng. Data 21: 78-80

Zavarzin, G. A., Nozhevnikova, A. N. (1977). Aerobic carboxydobacteria. Microb. Ecol. 3: 305-326

This paper was presented by Professor S. P. Meyers; it was accepted for printing on March 10, 1984 